\title{
Yield of Twelve Tanier Cultivars Grown With and Without Irrigation in East-Central Puerto Rico ${ }^{1}$
}

\author{
Héber Irizarry, Modesto Capiel, and Angel Acosta Matienzo² \\ ABSTRACT \\ Yields of 12 local and introduced tanier cultivars, genus Xanthosoma, were \\ compared under irrigated and nonirrigated conditions at the Gurabo Substa- \\ tion. Probably due to a wet and rather short growing season, irrigation did not \\ increase yields significantly. However, under irrigation all cultivars tended to \\ exceed the yield of their counterpart without irrigation. This was particularly \\ evident in Blanca del País, Rascana, and Viequera, with average yields \\ increased by $37 \%$.
}

\section{INTRODUCTION}

The edible aroid Xanthosoma, locally known as yautía or tanier, is a crop of economic importance in Puerto Rico and elsewhere in the Antilles. The starchy cormels, consumed in various ways, are rich in carbohydrates and minerals, thus contributing to basic human dietary requirements. Their caloric value runs to about 535 to the pound, compared to 570 for sweetpotatoes and 385 for white potatoes.

During the year 1973-74, the local farm value of this commodity was estimated at $\$ 4.3$ million. In spite of economic value, production per year has declined drastically since the beginning of the last decade. Abnormal rainfall distribution from year to year coupled with the highly selective moisture requirement of taniers may have contributed to the erratic yield behavior observed in this crop.

Abruña-Rodríguez et $\mathrm{al}^{3}$ found moisture availability an important factor in tanier production. They reported that tanier yields at Adjuntas, which exceeded those at Orocovis by $56 \%$ with cultivars Viequera, Rascana, and Bisley, were probably improved by a $25.4-\mathrm{cm}$ rainfall difference.

The present study evaluates the yielding capacity of 12 tanier cultivars planted in frequently irrigated and nonirrigated plots. Most of these cultivars were previously evaluated at five locations, Adjuntas, Orocovis, Gurabo, Naranjito, and Corozal, under normally existing rainfall patterns ${ }^{3,5}$.

${ }^{1}$ Manuscript submitted to Editorial Board February 25, 1976.

${ }^{2}$ Horticulturist, Agricultural Research Service, USDA, Agricultural Climatologist and Former Associate Agronomist, respectively, Agricultural Experiment Station, Mayagüez Campus, University of Puerto Rico, Río Piedras, P.R.

${ }^{3}$ Abruña-Rodríguez, F., Boneta-García, E. G., Vicente-Chandler, J., and Silva, S., Experiments on tanier production with conservation in Puerto Rico's Mountain Region, J. Agr. Univ. P.R., 51(2): 167-75, 1967. 


\section{MATERIALS AND METHODS}

The experiment was begun July 30, 1970, at the Gurabo Substation in a Toa clay loam (Mollisol) with pH 5.5.

Twelve local and introduced cultivars were arranged in a factorial design with six replications and planted in irrigated and nonirrigated plots. A brief taxonomic and morphological description of these taniers was published by Acosta-Matienzo ${ }^{4}$, and Acosta-Matienzo and VélezSantiago ${ }^{5}$. For the scope of this paper taniers Vinola and Morada were treated as seperate cultivars. However, since no distinctive separation could be established, both taniers may be classified as a single cultivar.

The main plots were $11 \times 11 \mathrm{~m}$, divided into subplots of $2.7 \times 3.7 \mathrm{~m}$. There were 24 experimental plants/cultivar/subplot, spaced $0.9 \times 0.5 \mathrm{~m}$ between rows and plants, respectively. Border rows were also provided around the main plots.

During land preparation the field was plowed to a depth of $19 \mathrm{~cm}$ and harrowed twice. Thereafter, the field was leveled and furrowed.

At planting, rhizome pieces with at least two germinal buds and weighing an average of $70 \mathrm{~g}$ were hand planted on the ridge. Before planting, seed pieces were dipped into a fungicide solution of $2.3 \mathrm{~g}$ Zerlate $^{6} / 1$ of water.

Two irrigation regimes were established after planting: frequent irrigation and no irrigation. The irrigation criterion was based on accumulated open pan evaporation data. Whenever 2.5 to $3.8 \mathrm{~cm}$ of water evaporated from the pan after subtracting the daily rainfall, plots were irrigated. Enough water was applied at each irrigation to compensate for surface runoff and seepage losses. To insure an adequate application, cylindrical gypsum blocks, located at 15.4-cm depth throughout the irrigated plots, were checked to verify that their readings corresponded to saturated conditions, about $300 \mathrm{ohms}$.

Irrigation was applied in the furrows by gravity. Before delivery into the main ditch, the water was measured in a rectangular weir. From the main ditch, floodgates diverted it into lateral canals. It was impounded into the furrows by plastic spiles $4.5 \mathrm{~cm}$ in diameter. The flow into the lateral canals was controlled to maintain a nearly constant head above the spiles.

${ }^{4}$ Acosta-Matienzo, A., Identificación y descripción de las variedades de yautía (Xanthosoma) en la colección de la Subestación de Gurabo, 1965, Est. Exp. Agr. Univ. P.R., Pub. Misc. 67, julio 1969.

5 __ and Vélez-Santiago, J., Yield trials with Xanthosoma varieties, J. Agr. Univ. P.R., 54(3): 562-9, 1970.

${ }^{6}$ Trade names are used in this publication solely for the purpose of providing specific information. Mention of a trade name does not constitute a guarantee or warranty of equipment or materials by the Agricultural Experiment Station of the University of Puerto Rico or an endorsement over other equipment or materiais not mentioned. 
To control weeds, $4.5 \mathrm{~kg} / \mathrm{ha}$ Ametryne were applied immediately after planting. Thereafter, plots were hand weeded when necessary.

At approximately 2 and 5 months after planting, $28 \mathrm{~g} /$ plant/application of 10-10-10-fertilizer were applied.

Records of daily rainfall, evaporation, and average maximum and minimum air temperatures were kept throughout the experiment.

Due to the abnormally high rainfall, plants were harvested approximately 9 months after planting, or 2 to 3 months before the expected harvesting. About $90 \%$ of the plantation showed maturity symptoms, and the tubers of early cultivars like Kelly were sprouting. Weight and number of marketable tubers were recorded, and mean tuber weight calculated.

TABLE 1. - Estimated marketable yield (metric tons per hectare) of 12 tanier cultivars grown with and without irrigation

\begin{tabular}{llc}
\hline \multirow{2}{*}{ Cultivar } & \multicolumn{2}{c}{ Yield $^{2}$} \\
\cline { 2 - 3 } & Irrigated & Nonirrigated \\
\hline Blanca del País & $17.8 \mathrm{a}$ & $13.9 \mathrm{a}$ \\
Choubutton & $14.9 \mathrm{ab}$ & $13.3 \mathrm{a}$ \\
Drearies & $14.8 \mathrm{abc}$ & $13.4 \mathrm{a}$ \\
Keliy & $14.6 \mathrm{abc}$ & $12.8 \mathrm{a}$ \\
Rascana & $14.3 \mathrm{abc}$ & $10.6 \mathrm{ab}$ \\
Viequera & $14.1 \mathrm{abc}$ & $9.6 \mathrm{ab}$ \\
Charanelle & $13.3 \mathrm{bc}$ & $12.6 \mathrm{a}$ \\
Vinola & $13.2 \mathrm{bc}$ & $10.2 \mathrm{ab}$ \\
Morada & $12.7 \mathrm{bc}$ & $10.3 \mathrm{ab}$ \\
Bisley & $11.4 \mathrm{bc}$ & $9.8 \mathrm{ab}$ \\
Inglesa & $11.1 \mathrm{bc}$ & $8.1 \mathrm{~b}$ \\
Barbados & $10.5 \mathrm{c}$ & $7.8 \mathrm{~b}$ \\
\hline
\end{tabular}

1 Values in the vertical columns followed by one or more letters in common do not differ significantly at $\mathrm{P}=0.05$.

\section{RESULTS AND DISCUSSION}

The statistical interpretation of the results showed no significant influence of irrigation on the yield attributes studied in the different cultivars: marketable weight, number of marketable tuber and mean tuber weight. All cultivars responded similarly to both frequently irrigated and nonirrigated treatments.

Data on marketable yields obtained with and without irrigation are presented in table 1 . Within the irrigated plots, the best yielding cultivars were Blanca del País, Choubutton, Drearies, Kelly, Rascana, and Viequera with $17.8,14.9,14.8,14.6,14.3$, and 14.1 metric tons/ha, respectively. Mean differences among these cultivars were not significant. However, Blanca del País, the highest yielder, showed significant differences at the $5 \%$ level, when compared with the remaining culti- 
vars. Within the nonirrigated plots, Blanca del País, Drearies, Choubutton, Kelly, and Charanelle were the superior cultivars with 13.9, $13.4,13.3,12.8$, and 12.6 metric tons/ha, respectively. Mean yields of all five cultivars were significantly superior to those obtained from Inglesa and Barbados but were not significantly higher than those from the other cultivars. In general the yield obtained without irrigation is consistent with yields reported elsewhere ${ }^{3,5}$ for most of these cultivars at other places in Puerto Rico.

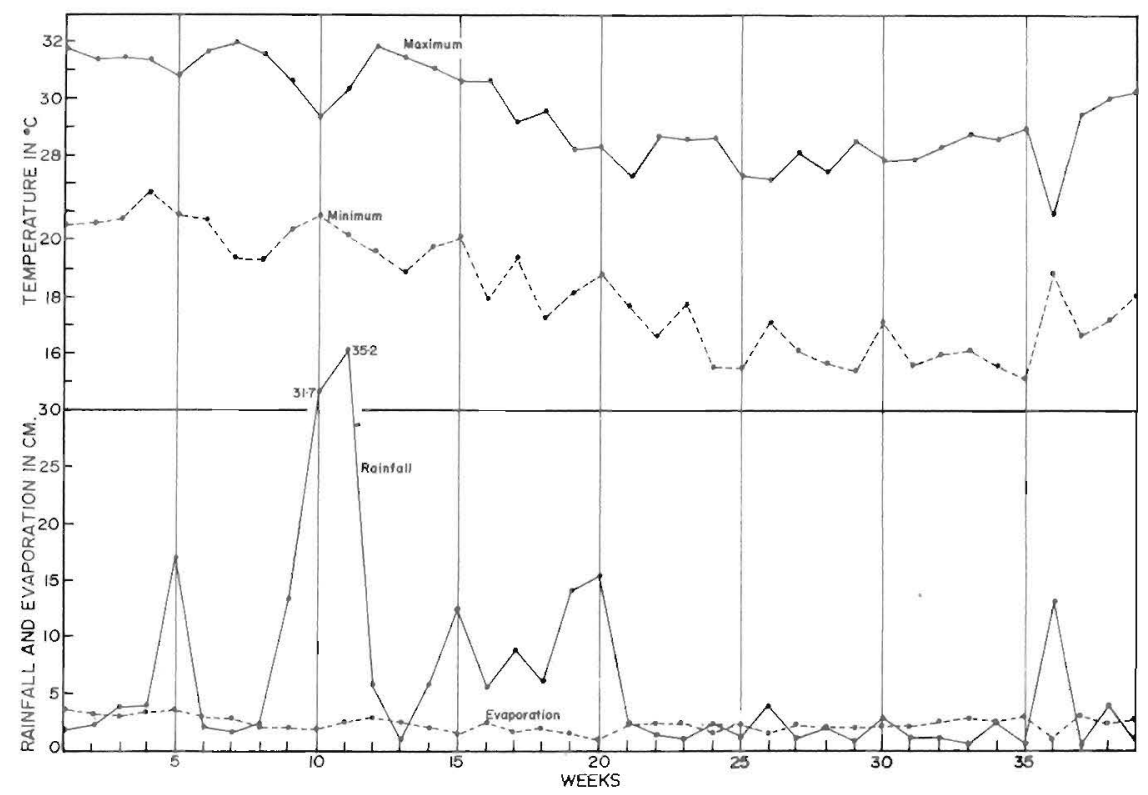

Fig. 1. - Weekly rainfall, evaporation, and maximum and minimum air temperatures recorded from July 30, 1970, to April 28, 1971, at the Gurabo Substation.

Rainfall during the growing period was $230.3 \mathrm{~cm}$. Of this amount, $188.8 \mathrm{~cm}$ fell during the first 20 weeks. Plots were irrigated five times to satisfy the scheduled irrigation frequency. Irrigations were applied in the 7th, 25th, 29th, 32nd and 35th weeks after planting (fig. 1). Probably due to the wet and rather short growing season, the five irrigations did not increase yields significantly even though the yields of all cultivars when irrigated tended to exceed their counterparts without irrigation (table 1). The most favorably affected high yielding cultivars were Blanca del País, Rascana, and Viequera, with an average yield increase of $37 \%$.

The two components of marketable yield are number and size of tubers, expressed herein as mean tuber weight. With respect to market- 
able tubers, the most prolific cultivar under both growing conditions was Blanca del País (table 2). Among the irrigated cultivars, the other more prolific yielders were Viequera, Drearies, Rascana, Choubutton, and Charanelle, with yields ranging from 110 to 115 tubers/plot. Differences among these cultivars were not significant, but Blanca del País produced significantly more tubers than Inglesa, Barbados, Kelly, Bisley, Vinola, and Morada. Within the nonirrigated treatment, the first six cultivars in addition to Kelly and Bisley were the most prolific. Detected differences among these cultivars were not significant, but

TABLE 2. - Number of marketable tubers produced by 12 tanier cultivars in irrigated and nonirrigated plots

\begin{tabular}{lcc}
\hline \multirow{2}{*}{ Cultivar } & \multicolumn{2}{c}{ Tubers per plot $^{-}$} \\
\cline { 2 - 3 } & Irrigated & Nonirrigated \\
\hline Blanca del País & $131.2 \mathrm{a}$ & $113.2 \mathrm{ab}$ \\
Viequera & $115.3 \mathrm{ab}$ & $89.2 \mathrm{abcd}$ \\
Drearies & $115.2 \mathrm{ab}$ & $98.2 \mathrm{abc}$ \\
Rascana & $114.2 \mathrm{abc}$ & $108.0 \mathrm{ab}$ \\
Choubutton & $112.8 \mathrm{abcd}$ & $106.7 \mathrm{ab}$ \\
Charanelle & $109.5 \mathrm{abcd}$ & $103.8 \mathrm{ab}$ \\
Inglesa & $104.2 \mathrm{bcd}$ & $86.0 \mathrm{bcd}$ \\
Barbados & $102.8 \mathrm{bcd}$ & $80.0 \mathrm{~cd}$ \\
Kelly & $98.7 \mathrm{bcd}$ & $93.8 \mathrm{abc}$ \\
Bisley & $91.5 \mathrm{bcd}$ & $98.7 \mathrm{abc}$ \\
Vinola & $90.7 \mathrm{~cd}$ & $79.7 \mathrm{~cd}$ \\
Morada & $89.0 \mathrm{~d}$ & $68.5 \mathrm{~d}$ \\
\hline
\end{tabular}

${ }^{1}$ Values in the vertical columns followed by one or more letters in common do not differ significantly at $\mathrm{P}=0.05$.

TABLE 3.-Mean tuber weight (grams) of 12 tanier cultivars grown with and without irrigation

\begin{tabular}{lcc}
\hline \multirow{2}{*}{ Cultivar } & \multicolumn{2}{c}{ Tuber weight } \\
\cline { 2 - 3 } & Irrigated & Nonirrigated \\
\hline Vinola & $145.2 \mathrm{a}$ & $127.0 \mathrm{ab}$ \\
Morada & $140.6 \mathrm{a}$ & $145.2 \mathrm{a}$ \\
Kelly & $140.6 \mathrm{a}$ & $131.5 \mathrm{a}$ \\
Blanca del País & $136.1 \mathrm{a}$ & $122.5 \mathrm{abc}$ \\
Drearies & $127.0 \mathrm{ab}$ & $131.5 \mathrm{a}$ \\
Choubutton & $127.0 \mathrm{ab}$ & $122.5 \mathrm{abc}$ \\
Rascana & $127.0 \mathrm{ab}$ & $95.3 \mathrm{~cd}$ \\
Viequera & $122.5 \mathrm{ab}$ & $97.8 \mathrm{bcd}$ \\
Bisley & $122.5 \mathrm{ab}$ & $90.7 \mathrm{~d}$ \\
Charanelle & $117.9 \mathrm{ab}$ & $117.9 \mathrm{abcd}$ \\
Inglesa & $104.3 \mathrm{~b}$ & $90.7 \mathrm{~d}$ \\
Barbados & $99.8 \mathrm{~b}$ & $95.3 \mathrm{~cd}$ \\
\hline
\end{tabular}

${ }^{1}$ Values in the vertical columns followed by one or more letters in common do not differ significantly at $\mathrm{P}=0.05$. 
Blanca del País, Rascana, Choubutton, and Charanelle yielded significantly more tubers than Barbados, Vinola, and Morada.

Again, the irrigation treatment did not increase the yield of marketable tubers. All cultivars except Bisley, however, produced more tubers when irrigated, notable Viequera, Barbados, and Morada, with an average tubers increase of $29 \%$ (table 2).

The cultivars bearing the largest or heaviest tubers in the irrigated plots were Vinola, Morada, Kelly, and Blanca del País (table 3.) Differences among them were not significant. However, all four cultivars produced significantly heavier tubers than Inglesa and Barbados. In the nonirrigated plots, cultivars bearing the largest tubers were Morada, Kelly, and Drearies. Differences among these taniers were not significant, but all produced significantly heavier tubers when compared to Rascana, Viequera, Bisley, Inglesa, and Barbados.

Although tuber size was not significantly increased by irrigation, most cultivars yielded heavier tubers in the irrigated plots. This was more pronounced in Bisley, Rascana, and Viequera, with a 35, 33, and $25 \%$ increase in tuber weight, respectively (table 3 ).

\section{RESUMEN}

Doce cultivares de yautía, de procedencia local e importados se sembraron en la Subestación de Gurabo en julio de 1970, para evaluar su capacidad productiva bajo dos regimenes de humedad del suelo: a) riego frecuente según lo indicaba la evaporación y acumulación de lluvia diaria y b) ningún riego suplementario. Las parcelas se regaban por infiltración.

Los resultados indican que, bajo las condiciones de una estación lluviosa y corta, el riego no aumentó significativamente los distintos atributos de producción pues los cultivares produjeron más o menos lo mismo con o sin riego. 